\title{
Pengaruh Biopolimer Pada Stabilitas Lereng Swelling soil
}

\author{
Dewi Amalia*1, Bagus Guritno ${ }^{2}$, Hendry $^{3}$, Geni Firuliadhim ${ }^{4}$ \\ ${ }^{1,2}$ Politeknik Negeri Bandung, Jl. Gegerkalong Hilir, Ds. Ciwaruga, Bandung \\ e-mail: ${ }^{1 *}$ dewi.amalia@ polban.ac.id, ${ }^{2}$ bagusguritno96@gmail.com
}

\begin{abstract}
Many studies have begun to develop the concept of cracked soil. The results of research related to cracked soil are able to answer the irregularities that occur, such as the difference in the results of the stability analysis which is considered safe with the conventional bishop method, while the conditions in the field are landslides. Swelling soil is soil that is susceptible to changes in water content. This type of soil is very prone to cracking. To build infrastructure on the swelling soil type, an improvement must be made, one of which is by mixing the swelling soil with biopolymer. The results of this biopolymer mixing are then modeled in the New Slope Stability Analysis Program (NSSAP) 1.0 which refers to the concept of cracked soil. From the analysis, it was found that the slope safety factor before improvement with biopolymer was 0.305 and the safety factor after improvement with biopolymer was 2.006. From the results of this study, it can be seen that the role of biopolymers in stabilizing swelling soil is quite large, which is around 558\%.
\end{abstract}

Keywords: cracked soil, swelling soil, slope stability, biopolymer

\begin{abstract}
Abstrak
Penelitian untuk mengembangkan konsep tanah retak (the concept of cracked soil) mulai banyak dilakukan. Hasil penelitian terkait cracked soil mampu menjawab kejanggalan yang terjadi, seperti perbedaan hasil analisis stabilitas yang dinilai aman dengan metode bishop konvesional, sedangkan kondisi di lapangan longsor. Swelling soil merupakan tanah yang rentan terhadap perubahan kadar air. Tanah jenis ini sangat rawan mengalami retakan (crack). Untuk membangun infrastruktur di atas tanah jenis swelling soil harus dilakukan suatu improvement, salah satunya dengan mencampurkan tanah swelling tersebut dengan biopolimer. Dalam pennelitian ini tanah dicampur dengan biopolymer chitosan sebesar $2 \%$, kemudian dilakukan siklus pengeringan secara siklik. Data indeks properties dan engineering kondisi awal dan akhir diamati. Hasil pencampuran biopolimer ini selanjutnya dimodelkan dalam program New Slope Stability Analysis Program (NSSAP) 1.0 yang mengacu pada the concept of cracked soil. Dari hasil analisis didapatkan bahwa safety factor lereng sebelum dilakukan improvement dengan biopolymer adalah 0,305 dan safety factor setelah dilakukan improvement dengan biopolymer adalah 2,006. Dari hasil penelitian ini terlihat bahwa peran biopolimer dalam meningkatkan stabilitas tanah (safety factor) swelling cukup besar, yaitu sekitar $558 \%$.
\end{abstract}

Kata kunci: Cracked soil, Swelling soil, Slope stability, Biopolimer 


\section{Pendahuluan}

The concept of cracked soil pada stabilitas lereng di Indonesia semakin berkembang. Konsep unik yang memandang crack berbeda dengan konsep yang ada sebelumnya (crack tidak hanya dianggap sebagai bidang lemah) ini dipelopori oleh Mochtar (Mochtar \& Hutagamissufardal, 2016). Stabilitas lereng yang dianalisa menggunakan metode yang ada selama ini menghasilkan SF > 1 yang berarti aman, tetapi di lapangan lereng longsor (Amalia et al., 2020,2018). Tidak hanya itu, ditemukan beberapa lereng dengan kemiringan cukup landai mengalami longsor pada saat hujan lebat, padahal jika dianalisis SF > 1 (Mochtar \& Hutagamissufardal, 2016) (Alexsander et al., 2017, 2018) telah berhasil melakukan validasi terhadap the concept of cracked soil dengan penelitian langsung di lapangan. Penelitian (Amalia et al., 2019) mampu memfasilitasi kebutuhan menganalisis lereng secara numerik menggunakan the concept of cracked soil. Dari sini dapat disimpulkan bahwa the concept of cracked soil layak digunakan dan sangat disarankan untuk menganalisis lereng yang retak. Tanah ekspansif, yaitu tanah yang memiliki sifat mengembang saat jenuh air dan susut saat dalam keadaan kering, menyebabkan perubahan volume yang ekstrim dan dapat menyebabkan struktus diatasnya menjadi labil (Pramudyo, Tulus; Sollu Willian Pradana; Hemawan, 2019). Tanah kembang susut dibentuk melalui periode kering yang panjang dan diikuti dengan periode basah yang pendek (Suherman, 2005). Tanah kembang susut (swelling soil) merupakan tanah yang sensitif terhadap perubahan kadar air. Swelling soil rentan terhadap keretakan (crack). Solusi perbaikan tanah kembang susut (swelling soil) yang dapat dilakukan diantaranya adalah penggantian tanah, mengisolasi tanah dari air, meningkatkan tegangan kontak di bawah pondasi dangkal, menggunakan tiang pancang dengan ujung yang diperbesar (Elmannaey et al., 2021). Solusi lain yaitu stabilisasi tanah, yaitu dengan menginjeksi bahan kimia ke dalam tanah. Tujuan utama stabilisasi kimia tanah umumnya berkaitan dengan peningkatan kekuatan dan penurunan permeabilitas, kompresibilitas dan potensi likuifaksi.

Campuran semen konvensional adalah bahan kimia yang sering dipakai dalam stabilisasi lereng. Penggunaan semen dapat meningkatkan nilai sudut geser $\phi$ kisaran $32^{\circ}-43$ (Chen et al., 2020). Hanya saja, hal tersebut dapat menimbulkan permasalahan lingkungan yang tidak diinginkan seperti emisi karbon, menurut (Setiawati et al., 2015) industri semen menyumbang 1 ton $\mathrm{CO}_{2} /$ ton produksinya. Untuk meminimalisir permasalah tersebut, perkuatan ramah lingkungan dapat menjadi alternatif pengganti campuran semen. Biopolimer adalah bahan tambah performa tinggi serta ramah lingkungan. Ikatan partikel antara biopolimer dan tanah dapat mengurangi hidrolik konduktivitas dan meningkatkan kohesi tanah. Selain itu penggunaan biopolimer juga dapat meningkatkan kekuatan tanah yang dipengaruhi dari konsentrasi, waktu curing, dan jenis tanah yang digunakan (Chen et al., 2020). Pengujian kekuatan campuran biopolimer dan tanah telah banyak dilakukan, seperti pada Gambar 1 dapat diketahui bahwa pemberian biopolimer dapat memberikan tambahan compressive strenght dari tanah awal $181 \mathrm{kPa}$ menjadi paling tinggi 7,087 kPa dengan bahan tambah biopolimer XG 4\% (Soldo, 2020).

Hanya saja penelitian terkait biopolymer masih sedikit dilakukan di Indonesia, terutama pengaruh biopolymer dalam meningkatkan stabilitas lereng tanah swelling soil. Untuk itu, paper ini akan membahas pengaruh biopolimer sebagai zat penstabil untuk swelling soil. Selain mempelajari pengaruh biopolimer pada swelling soil, penelitian ini bertujuan juga untuk menyelidiki efektivitas penggunaan biopolimer dalam meningkatan stabilitas lereng berdasarkan the concept of cracked soil.

\section{Metode Penelitian}

Sampel tanah yang digunakan adalah tanah terganggu (disturbed) dengan kedalaman adalah 2 meter dan tanah tidak terganggu (undisturbed) yang diambil dari Ruas Jalan Karanggede - Juwangi. Teknik pengambilan benda uji untuk penelitian ini dilakukan langsung di lapangan dengan metode hand boring. Hand boring merupakan pengeboran secara manual dengan menggunakan tangan untuk 
mengambil benda uji contoh tanah tidak terganggu yang dimasukkan pada tabung pipa standar berdiameter 4 inchi untuk keperluan penyelidikan laboratorium. Titik pengambilan benda uji direncanakan adalah dua titik yaitu pada STA 8+000 dan STA 12+500 dengan satu titik pengambilan maksimal sedalam 10 meter. Titik tersebut adalah titik yang diijinkan oleh pemda setempat untuk diambil samplenya. Pengambilan benda uji yang diperlukan lebih lanjut dapat dilihat pada Tabel 3.1. Dari dua titik tersebut didapatkan 7 tabung tanah tidak terganggu dengan kedalaman yang bervariasi dan satu karung penuh $\pm 20 \mathrm{~kg}$ tanah terganggu. Setiap tabung tanah tidak terganggu diperuntukkan dalam pengujian sifat fisis dan mekanis tanah untuk keperluan simulasi numerik (propertis tanah). Sedangkan tanah terganggu digunakan untuk pencampuran dengan biopolimer serta pengeringan siklik.

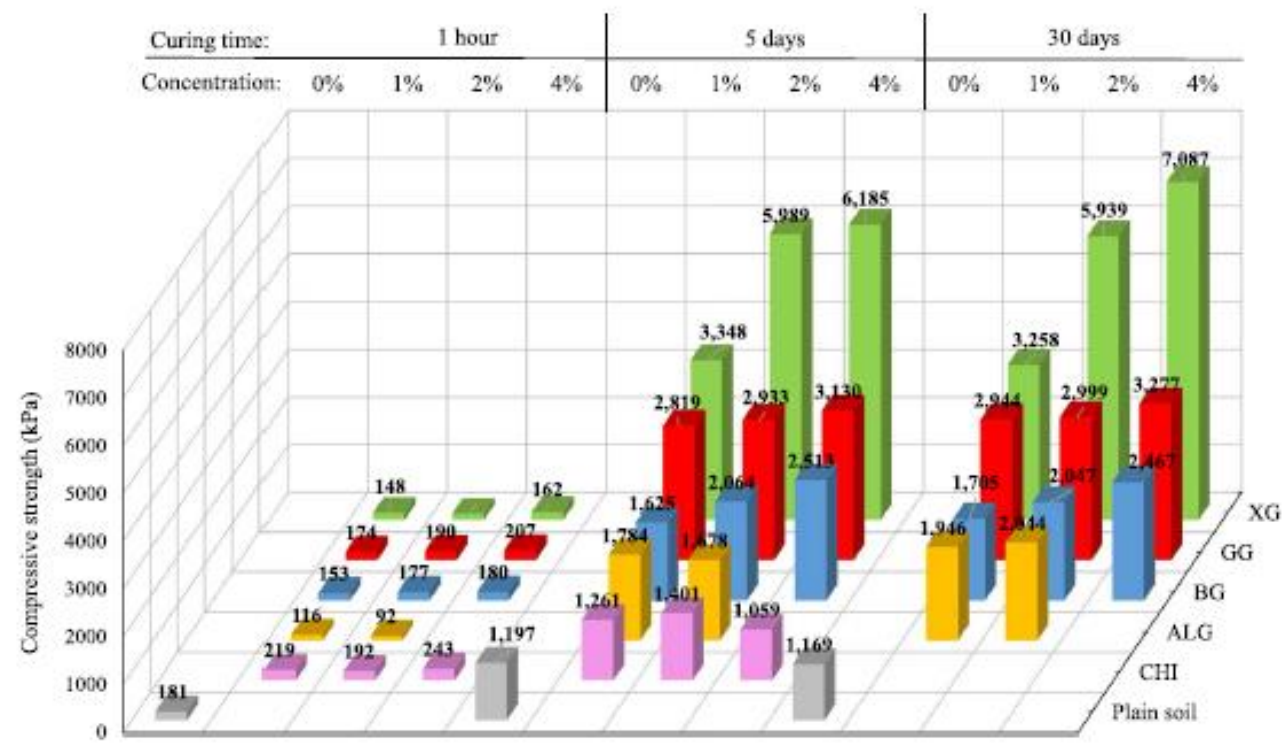

Gambar 1. Hasil uji tekan dengan parameter waktu, jenis biopolimer, dan konsentrasi biopolymer (Soldo, 2020)

\subsection{Prosedur Pengujian Propertis Benda Uji}

Benda uji ini diuji berdasarkan sifatnya yang terbagi menjadi dua, yakni pengujian sifat fisis tanah (pengujian kadar air, berat jenis, attenberg limit, dan analisa butiran) dan pengujian sifat mekanis tanah (pengujian tekan bebas dan geser langsung). Pengujian tersebut dilakukan berdasarkan referensi ASTM yang dapat memberikan prosedur pengujian yang benar. Tabel 1 memberikan jenis pengujian beserta referensi yang digunakan, misalnya pengujian kadar air menggunakan referensi ASTM Standards, Vol. 04.08. D 2216.

Tabel 1. Acuan Pengujian

\begin{tabular}{cll}
\hline No & \multicolumn{1}{c}{ Jenis Pengujian } & \multicolumn{1}{c}{ Referensi } \\
\hline $\mathbf{1}$ & Sifat fisis & \\
a & Kadar air & ASTM Standards, Vol. 04.08. D 2216 \\
b & Spesific Gravity (GS) & ASTM Standards, Vol.04.08. D 854 \\
c & Attenberg Limit & ASTM Standards, Vol.04.08. D 4318 \\
d & Analisa Butiran & ASTM Standards, Vol.04.08. D 422-63 \\
& & \\
$\mathbf{2}$ & Sifat mekanis & ASTM Standards, Vol. 04.08. D 2166 \\
a & Uji tekan bebas (UCS) & ASTM Standards, Vol. 04.08. D 3080-98. \\
b & Geser langsung &
\end{tabular}




\subsection{Pengeringan Siklik}

Benda uji dikeringkan secara siklik, pengeringan siklik yang dimaksudkan di sini adalah melakukan pengeringan dengan menggunakan dua suhu yang berbeda (suhu ruang selama 24 jam dan suhu ekstrim $105{ }^{\circ} \mathrm{C}$ selama 4 jam). Suhu ruang yang digunakan mengikuti Peraturan Pemerintah Nomor 2 Tahun 1989 tentang standar nasional satuan ukuran, yakni $20^{\circ} \mathrm{C}$ dan pengamatan dilakukan setelah 24 jam. Suhu ekstrim yang digunakan mengikuti pengujian sifat fisis tanah yang melakukan pengovenan pada suhu $105{ }^{\circ} \mathrm{C} \pm 5^{\circ} \mathrm{C}$, pada pengujian suhu ekstrim dilakukan pengamatan setiap 15 menit, setelah dua jam pengeringan benda uji diberikan tambahan air hingga mencapai kadar air optimumnya dan kembali dimasukkan kedalam oven. Pengamatan dilakukan tetap setiap 15 menit hingga pengovenan selesai setelah dua jam pengeringan (Izzo \& Miletić, 2019). Pengamatan yang dimaksudkan adalah pengambilan gambar termal untuk kemudian dilakukan analisis citra digital.

\subsection{Analisis Stabilitas Lereng}

Penelitian ini menggunakan suatu program analisa stabilitas lereng bernama NSSAP 1.0 (Slope Stability Analysis Programme 1.0). Program ini mengadopsi prinsip Limit Equilibrium Method. Perbedaan yang sangat menonjol adalah kemudahannya dalam memasukan (input) data lapangan (data geolistrik) secara langsung. Perbadaan lainnya adalah program ini telah menerapkan konsep cracked soil dalam menganalisa stabilitas lereng.Simulasi stabilitas lereng menggunakan software MATLAB R2013a dengan memanfaatkan syntax aritmatika, logika, dan modul GUI(Graphic User Interface). Perancangan program simulasi ini terbagi atas dua komponen penting yaitu perancangan logika program dengan format $m$-files dan perancangan GUI dengan format -figure.

Alur penggunaan program dimulai dengan menggambar lereng beserta lapisan tanah dan muka air tanah. Urutan gambar diawali dengan menggambar lereng terlebih dahulu, kemudian lapisan tanah, muka air tanah, dan terakhir adalah posisi cracks. Pendefinisian banyak titik ketika menggambar dilakukan pertama kali sebelum mulai merancang gambar lereng, lapisan tanah, dan muka air tanah. Selanjutnya pengisikan posisi perkiraan bidang longsor (titik initation dan termination) dan berapa jumlah tampilan safety factor yang diinginkan. Pengisian parameter-parameter dimaksudkan untuk menyediakan nilai-nilai yang akan digunakan selama proses jalannya program, seperti letak koordinat maksimal dan minimal dari jari-jari dan pusat lingkaran, nilai berat volume, kohesi, dan sudut geser dalam tanah pada tiap lapisan tanah. Parameter-parameter tersebut perlu diisi agar program dapat melakukan tugas untuk menampilkan nilai keamanan yang seusai dengan rancangan gambar lereng. Tahap terakhir adalah tahap perhitungan safety factor.

\section{Hasil dan Pembahasan}

Hasil penelitian karakteristik tanah asli meliputi 2 (dua) kelompok yaitu sifat fisis dan sifat mekanis tanah. Sifat fisis terdiri dari Kadar air tanah, berat volume, batas-batas atterberg, analisa distribusi butiran, dan berat jenis tanah, sedangkan sifat mekanis terdiri dari tekan bebas dan geser langsung, untuk lebih rinci data hasil pengujian laboratorium dapat dilihat pada Tabel 2. Berikut ini adalah penjelasan dan pembahasan dari hasil pengujian tanah di laboratorium.

\subsection{Sifat fisis dan mekanis}

Tabel 2 menunjukan bahwa tanah pada ruas Jalan Karanggede - Juwangi bersifat Homogen (secara keseluruhan memiliki kesamaan sifat) dan merupakan jenis tanah berbutir halus dengan presentase ukuran butir rata-rata 55,2\% (30,9\% silt dan $24,3 \%$ clay) tanah lolos ayakan No. 200. Nilai batas cair (LL) rata-rata $60,5 \%$, batas plastis (PL) rata-rata $22,2 \%$, dan nilai indeks plastisitas (IP) rata-rata $38,3 \%$ sehingga menurut klasifikasi AASTHO tanah tersebut merupakan tanah lempung dengan sifat plastisitas tinggi dan masuk dalam kelompok tanah A-7-6 dan terlihat pada Tabel 2, berat jenis (Gs) berkisar pada 2,65. Berdasarkan data laboratorium yang merujuk pada klasifikasi AASTHO, maka 
rating atau penilaian tanah pada ruas Jalan Karanggede - Juwangi sebagai sebagai bahan tanah dasar adalah $\mathrm{poor} / \mathrm{jelek}$.

Tabel 2 menunjukan tingkat keaktifan benda uji sebesar 1,575 yang menandakan potensi pengembangan benda uji tinggi (Ac > 1,25) (W. G. Holtz \& H. J. Gibbs, 1956). Nilai Indeks Plastisitas (IP) juga dapat digunakan sebagai parameter potensi pengembangan, nilai IP yang lebih besar dari 35\% menandakan tingkat pengembangan sangat tinggi (W. G. Holtz \& H. J. Gibbs, 1956). Korelasi keduanya dapat dimuat pada grafik potensi kembang susut dengan sumbu y adalah Ac dan sumbu x adalah Fraksi Lempung (CF). Berdasarkan Gambar 1 dapat diketahui bahwa tanah pada ruas Jalan Karanggede - Juwangi memiliki potensi kembang susut yang tinggi. Dilihat dari sifat kembang susut tanah yang tinggi tersebut maka kontribusinya terhadap kerusakan sangat besar karena melalui sifat ini maka besar kemungkinan terjadinya perubahan kadar air dalam tanah juga potensi untuk terjadi pengembangan dan penyusutan pada saat peralihan iklim (temperatur) dari musim hujan ke musim kemarau sangat besar (Wardana, 2009), hal tersebut berdampak pada kerusakan jalan berupa terjadinya retakan yang dapat teridentifikasi melalui permukaan jalan yaitu terjadi kerusakan amblas yang diikuti oleh pelepasan butiran dan menyebabkan lubang sehingga memberikan dampak berkelanjutan yang lebih parah.

Hasil pengujian tanah pada ruas Jalan Karanggede - Juwangi Tabel 2 juga menunjukkan nilai kerapatan kering maksimum $(\gamma \mathrm{d})$ rata-rata sebesar $1,067 \mathrm{~g} / \mathrm{cm}^{3}$, kerapatan basah maksimum $(\gamma \mathrm{m})$ rata-rata sebesar $1,469 \mathrm{~g} / \mathrm{cm}^{3}$, kadar air (w) optimum rata-rata adalah $37,6 \%$, dan memiliki rata-rata nilai kuat tekan aksial ( $\mathrm{q}_{\mathrm{u}}$ ) maksimum sebesar $0,209 \mathrm{~kg} / \mathrm{cm}^{2}$ dengan nilai sensitifitas (St) adalah 1,281 (tidak sensitif <2) (Nursar et al., 2015). Dari data nilai tekan dapat diketahi bahwa tanah dengan potensi kembang susut tinggi memiliki sifat sangat lunak $\left(\mathrm{q}_{u}<0,225\right)$ (Nursar et al., 2015).

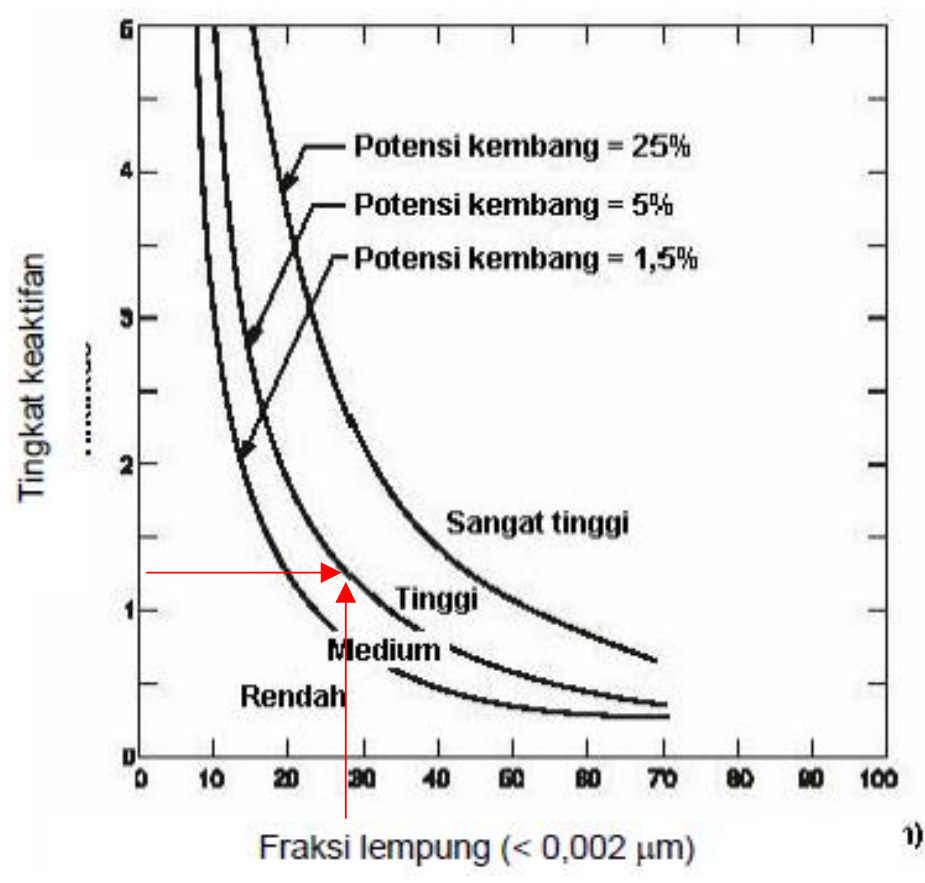

\author{
Gambar 1 Klasifikasi potensi kembang susut \\ (Seed, 1962 dalam (Departemen Pekerjaan Umum, 2004))
}




\section{Grafik Seed}

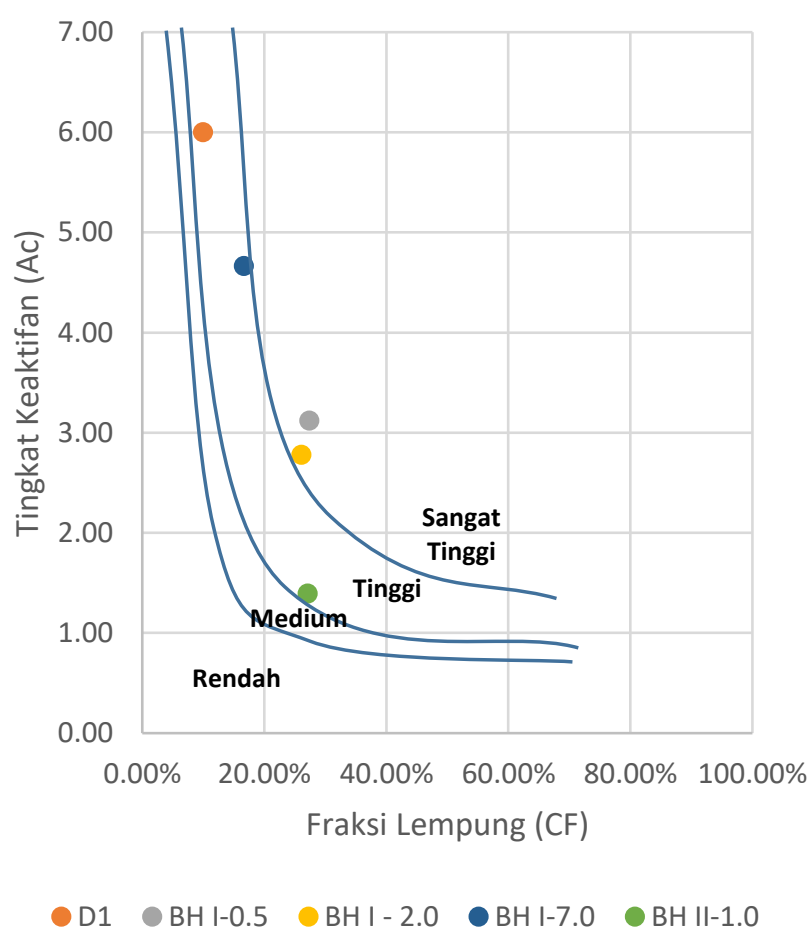

Gambar 2. Grafik Hubungan antara Fraksi Lempung dengan Tingkat Keaktifan

\subsection{Analisis stabilitas lereng kondisi Inisial}

Analisis stabilitas lereng kondisi inisial dilakukan menggunakan metode Bishop pada program NSSAP 1.0 dapat dilihat pada Gambar 3.

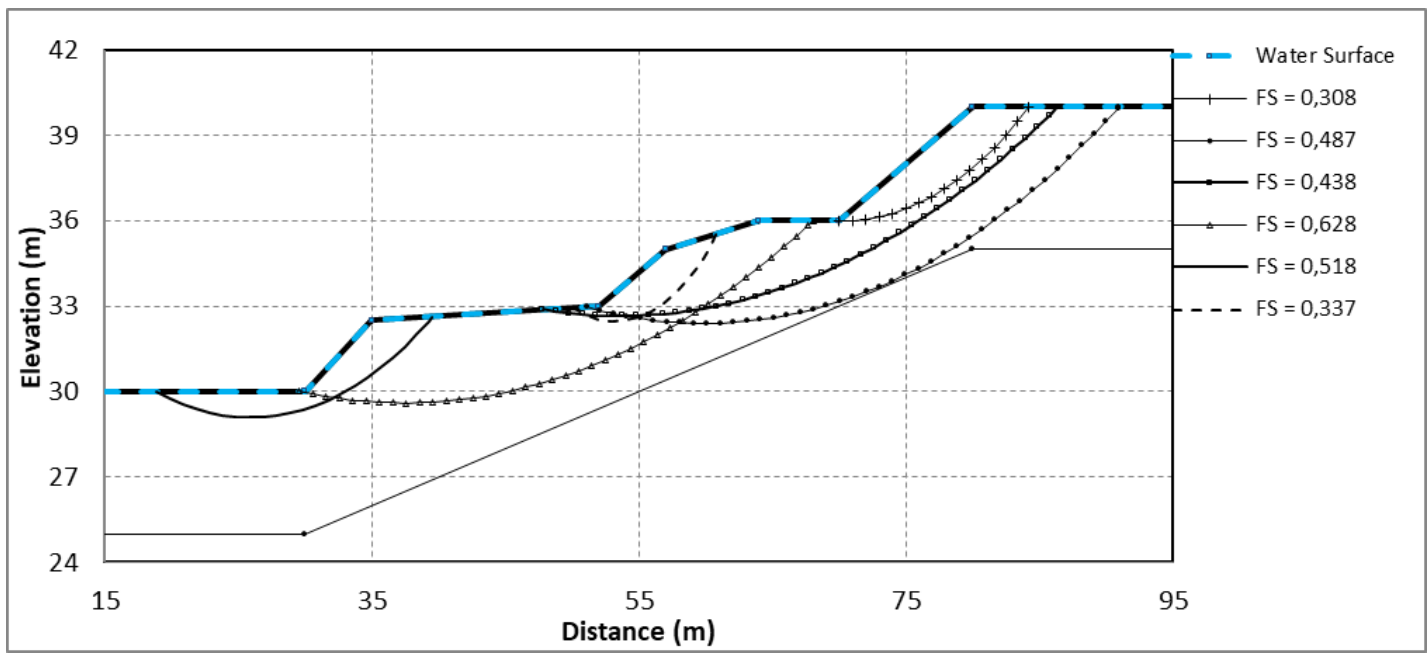

Gambar 3. Analisis Stabilitas Lereng Kondisi Inisial dengan The Concept of Cracked Soil 
Tabel 2. Pengujian Laboratorium

\begin{tabular}{|c|c|c|c|c|c|c|c|c|c|c|c|c|c|c|c|c|c|c|c|c|c|}
\hline \multirow[b]{2}{*}{ No } & \multirow{2}{*}{$\begin{array}{l}\text { Bore } \\
\text { Hole } \\
\text { No. } \\
\end{array}$} & \multirow[b]{2}{*}{\begin{tabular}{|c|} 
Sample \\
No.
\end{tabular}} & \multirow[b]{2}{*}{ Dept. } & \multicolumn{7}{|c|}{ Natural State } & \multicolumn{4}{|c|}{ Grain Size Distribution } & \multicolumn{3}{|c|}{ Attenberg Limit } & \multicolumn{2}{|c|}{ UCS } & \multicolumn{2}{|c|}{ Direct Shear } \\
\hline & & & & w & Sr & $\begin{array}{c}\gamma \mathrm{m} \\
\left(\mathrm{g} / \mathrm{cm}^{3}\right)\end{array}$ & $\begin{array}{c}\gamma \mathrm{d} \\
\left(\mathrm{g} / \mathrm{cm}^{3}\right)\end{array}$ & e & $\mathrm{n}$ & Gs & Gravel & Sand & Silt & Clay & LL & PL & IP & $\begin{array}{c}\text { qu } \\
\left(\mathrm{kg} / \mathrm{cm}^{2}\right)\end{array}$ & St & $\begin{array}{c}\mathrm{C} \\
\left(\mathrm{kg} / \mathrm{cm}^{2}\right)\end{array}$ & $\begin{array}{l}\phi \\
\left({ }^{\circ}\right)\end{array}$ \\
\hline 1 & - & D1 & $0.5-2.0$ & $43.05 \%$ & $86.30 \%$ & 1.579 & 1.117 & 1.3134 & 0.5677 & 2.6331 & $0.00 \%$ & $49.20 \%$ & $40.83 \%$ & $9.98 \%$ & $54.95 \%$ & \begin{tabular}{|l|}
$21.81 \%$ \\
\end{tabular} & $33.14 \%$ & & & & \\
\hline 2 & \multirow{5}{*}{ BH I } & BHI- 0.5 & $0.5-1.0$ & $43.26 \%$ & $81.84 \%$ & 1.561 & 1.084 & 1.404 & 0.584 & \begin{tabular}{|l|}
2.656 \\
\end{tabular} & $0.00 \%$ & $49.31 \%$ & $23.31 \%$ & $27.38 \%$ & $79.03 \%$ & \begin{tabular}{|l|}
$24.76 \%$ \\
\end{tabular} & $54.27 \%$ & 0.218 & 1.173 & 0.110 & 12.198 \\
\hline 3 & & \begin{tabular}{|l}
$\mathrm{BHI}-2.0$ \\
\end{tabular} & $2.0-2.5$ & $36.02 \%$ & $59.62 \%$ & 1.370 & 1.000 & \begin{tabular}{|l|l|}
1.604 \\
\end{tabular} & 0.616 & \begin{tabular}{|l|}
2.655 \\
\end{tabular} & $0.00 \%$ & $49.88 \%$ & $24.05 \%$ & $26.08 \%$ & $68.03 \%$ & $23.38 \%$ & $44.65 \%$ & 0.239 & 1.069 & 0.108 & 13.955 \\
\hline 4 & & BHI-4.0 & $4.0-4.5$ & & & & & & & & & & & & & & & & & & \\
\hline 5 & & BHI-5.0 & $5.0-5.5$ & & & & & & & & & & & & & & & & & & \\
\hline 6 & & BHI-7.0 & $7.0-7.5$ & $22.61 \%$ & $42.21 \%$ & 1.302 & 1.076 & 1.424 & 0.587 & \begin{tabular}{|l|}
2.659 \\
\end{tabular} & $0.00 \%$ & $44.56 \%$ & $38.81 \%$ & $16.63 \%$ & $50.00 \%$ & \begin{tabular}{|l|}
$19.09 \%$ \\
\end{tabular} & $30.91 \%$ & 0.189 & 1.458 & 0.116 & 10.572 \\
\hline 7 & \multirow{2}{*}{ BH II } & BH II- 1.0 & $1.0-1.5$ & $48.56 \%$ & $95.31 \%$ & 1.643 & 1.107 & 1.354 & 0.575 & \begin{tabular}{|l|l|}
2.657 \\
\end{tabular} & $0.00 \%$ & $35.43 \%$ & $37.45 \%$ & $27.12 \%$ & $45.46 \%$ & $21.58 \%$ & $23.88 \%$ & 0.190 & 1.425 & 0.136 & 10.171 \\
\hline 8 & & BH II - 3.0 & 5-3.25 & & & & & & & & & & & & & & & & & & \\
\hline
\end{tabular}

\begin{tabular}{|c|c|c|c|c|c|c|c|c|c|c|c|c|c|}
\hline \multirow{2}{*}{ No } & \multirow{2}{*}{$\begin{array}{c}\begin{array}{c}\text { Bore Hole } \\
\text { No. }\end{array} \\
\end{array}$} & \multirow{2}{*}{\begin{tabular}{c|} 
Sample \\
No.
\end{tabular}} & \multirow{2}{*}{ Dept. } & \multicolumn{4}{|c|}{ Grain Size Distribution } & \multicolumn{3}{|c|}{ Attenberg Limit } & \multicolumn{3}{|l|}{ Klasifikasi } \\
\hline & & & & Gravel & Sand & Silt & Clay & $\mathrm{LL}$ & $\mathrm{PL}$ & IP & USDA & USCS & AASTHO \\
\hline 1 & - & D1 & $0.5-2.0$ & $0.00 \%$ & $49.20 \%$ & $40.83 \%$ & $9.98 \%$ & $54.95 \%$ & $21.81 \%$ & $33.14 \%$ & Loam (Lempung) & $\mathrm{CH}$ & A-7-6 \\
\hline 2 & \multirow{5}{*}{ BH I } & $\mathrm{BHI}-0.5$ & $0.5-1.0$ & $0.00 \%$ & $49.31 \%$ & $23.31 \%$ & $27.38 \%$ & $79.03 \%$ & $24.76 \%$ & $54.27 \%$ & \begin{tabular}{|c|} 
Sandy Clay Loam (Lempung \\
Liat Berpasir)
\end{tabular} & $\mathrm{CH}$ & A-7-6 \\
\hline 3 & & $\mathrm{BHI}-2.0$ & $2.0-2.5$ & $0.00 \%$ & $49.88 \%$ & $24.05 \%$ & $26.08 \%$ & $68.03 \%$ & $23.38 \%$ & $44.65 \%$ & $\begin{array}{c}\text { Sandy clay loam (Lempung } \\
\text { liat berpasir) }\end{array}$ & $\mathrm{CH}$ & A-7-6 \\
\hline 4 & & BHI -4.0 & $4.0-4.5$ & $0.00 \%$ & $0.00 \%$ & $0.00 \%$ & $0.00 \%$ & $0.00 \%$ & $0.00 \%$ & $0.00 \%$ & & & \\
\hline 5 & & BH I- 5.0 & $5.0-5.5$ & $0.00 \%$ & $0.00 \%$ & $0.00 \%$ & $0.00 \%$ & $0.00 \%$ & $0.00 \%$ & $0.00 \%$ & & & \\
\hline 6 & & BHI- 7.0 & $7.0-7.5$ & $0.00 \%$ & $44.56 \%$ & $38.81 \%$ & $16.63 \%$ & $50.00 \%$ & $19.09 \%$ & $30.91 \%$ & Loam (Lempung) & $\mathrm{CH}$ & A-7-6 \\
\hline 7 & \multirow{2}{*}{ BH II } & BH II- 1.0 & $1.0-1.5$ & $0.00 \%$ & $35.43 \%$ & $37.45 \%$ & $27.12 \%$ & $45.46 \%$ & $21.58 \%$ & $23.88 \%$ & Clay Loam (Lempung Berliat) & $\mathrm{CL}$ & A-7-6 \\
\hline 8 & & BH II - 3.0 & $2.75-3.25$ & $0.00 \%$ & $0.00 \%$ & $0.00 \%$ & $0.00 \%$ & $0.00 \%$ & $0.00 \%$ & $0.00 \%$ & & & \\
\hline
\end{tabular}

\begin{tabular}{|c|c|c|c|c|c|c|c|c|c|c|c|c|c|c|c|c|c|c|}
\hline \multirow{2}{*}{ No } & \multirow{2}{*}{\begin{tabular}{|c|} 
Bore \\
Hole No.
\end{tabular}} & \multirow{2}{*}{\begin{tabular}{c|} 
Sample \\
No.
\end{tabular}} & \multirow{2}{*}{ Dept. } & \multicolumn{4}{|c|}{ Grain Size Distribution } & \multicolumn{3}{|c|}{ Attenberg Limit } & \multirow{2}{*}{$\begin{array}{c}\text { Ac } \\
\text { (skempton) }\end{array}$} & \multirow{2}{*}{$\begin{array}{c}\text { Ac } \\
\text { (Seed) }\end{array}$} & \multicolumn{3}{|c|}{ Potensi Pengembangan } & \multicolumn{2}{|c|}{ Tingkat Keaktifan } & \multirow{2}{*}{$\begin{array}{c}\begin{array}{c}\text { Persentase } \\
\text { Mengembang }\end{array} \\
\text { Metode } \\
\text { Arbianto } \\
\end{array}$} \\
\hline & & & & Gravel & Sand & Silt & Clay & แL & $\mathrm{PL}$ & IP & & & $\begin{array}{l}\text { Metode } \\
\text { Chen }\end{array}$ & $\begin{array}{c}\text { Metode Holz } \\
\text { \& Gibbs }\end{array}$ & $\begin{array}{l}\text { Metode } \\
\text { Ramen }\end{array}$ & $\begin{array}{c}\text { Metode } \\
\text { Skempton }\end{array}$ & $\begin{array}{c}\text { Metode } \\
\text { Seed }\end{array}$ & \\
\hline 1 & $\cdot$ & D1 & $0.5-2.0$ & $0.00 \%$ & $49.20 \%$ & $40.83 \%$ & $9.98 \%$ & $54.95 \%$ & $21.81 \%$ & $33.14 \%$ & 3.32 & 6.00 & Tinggi & Tinggi & $\begin{array}{c}\text { Sangat } \\
\text { Tinggi }\end{array}$ & Aktif & Tinggi & $14.86 \%$ \\
\hline 2 & \multirow{5}{*}{ BHI } & BHI-0.5 & $0.5-1.0$ & $0.00 \%$ & $49.31 \%$ & $23.31 \%$ & $27.38 \%$ & $79.03 \%$ & $24.76 \%$ & $54.27 \%$ & 1.98 & 3.12 & $\begin{array}{l}\text { Sangat } \\
\text { Tinggi }\end{array}$ & Sangat Tinggi & $\begin{array}{l}\text { Sangat } \\
\text { Tinggi }\end{array}$ & Aktif & $\begin{array}{c}\text { Sangat } \\
\text { Tinggi }\end{array}$ & $40.92 \%$ \\
\hline 3 & & BHI-2.0 & $2.0-2.5$ & $0.00 \%$ & $49.88 \%$ & $24.05 \%$ & $26.08 \%$ & $68.03 \%$ & $23.38 \%$ & $44.65 \%$ & 1.71 & 2.78 & Tinggi & Sangat Tinggi & $\begin{array}{c}\text { Sangat } \\
\text { Tinggi }\end{array}$ & Aktif & $\begin{array}{c}\text { Sangat } \\
\text { Tinggi }\end{array}$ & $27.29 \%$ \\
\hline 4 & & BH $1-4.0$ & $4.0-4.5$ & $0.00 \%$ & $0.00 \%$ & $0.00 \%$ & $0.00 \%$ & $0.00 \%$ & $0.00 \%$ & $0.00 \%$ & & & & & & & & \\
\hline 5 & & BH I-5.0 & $5.0-5.5$ & $0.00 \%$ & $0.00 \%$ & $0.00 \%$ & $0.00 \%$ & $0.00 \%$ & $0.00 \%$ & $0.00 \%$ & & & & & & & & \\
\hline 6 & & BH I- 7.0 & $7.0-7.5$ & $0.00 \%$ & $44.56 \%$ & $38.81 \%$ & $16.63 \%$ & $50.00 \%$ & $19.09 \%$ & $30.91 \%$ & 1.86 & 4.67 & Tinggi & Tinggi & Tinggi & Aktif & Tinggi & $12.95 \%$ \\
\hline 7 & \multirow{2}{*}{ BH II } & BH II- 1.0 & $1.0-1.5$ & $0.00 \%$ & $35.43 \%$ & $37.45 \%$ & $27.12 \%$ & $45.46 \%$ & $21.58 \%$ & $23.88 \%$ & 0.88 & 1.39 & Tinggi & Sedang & Tinggi & Normal & Tinggi & $7.94 \%$ \\
\hline 8 & & BH II- 3.0 & $2.75-3.25$ & $0.00 \%$ & $0.00 \%$ & $0.00 \%$ & $0.00 \%$ & $0.00 \%$ & $0.00 \%$ & $0.00 \%$ & & & & & & & & \\
\hline
\end{tabular}

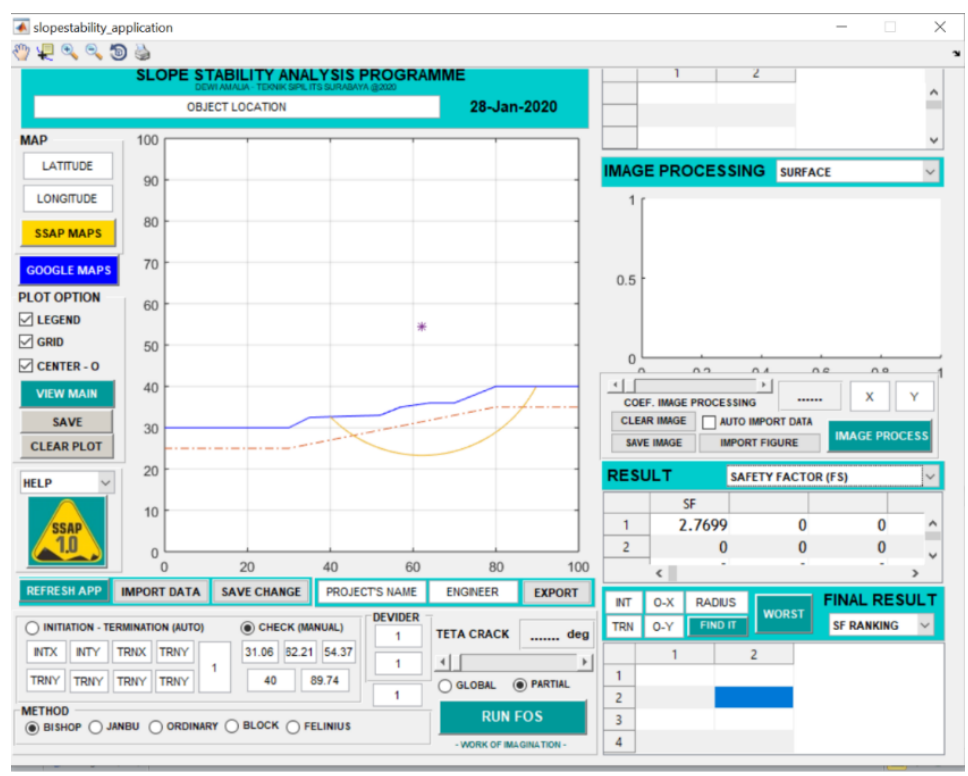

Gambar 4. Contoh tampilan hasil running NSSAP 1.0 


\subsection{Pengaruh Stabilisasi Tanah Ekspansive soil dengan Biopolimer Chitosan 2\%}

Dalam analisa ini, tanah sedalam retakan dimodelkan berperilaku sebagai tanah pasir (behaving like sand) dengan parameter $\mathrm{c}_{\mathrm{crack}} \neq \mathrm{c}_{\text {tanah }} ; \mathrm{c}_{\mathrm{c}}=0$ (Tabel 3); dan mengalami pore water pressure built up. Hasil analisis NSSAP 1.0 bisa dilihat pada Gambar 5.

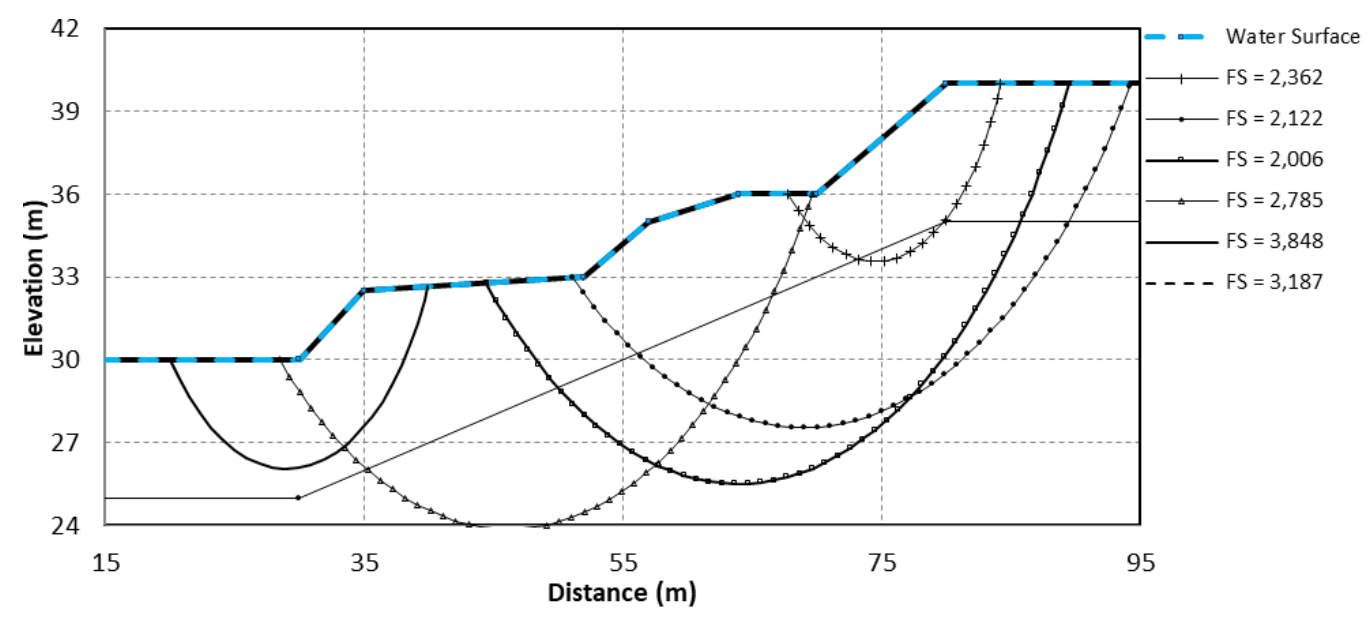

Gambar 5 Analisis Stabilitas Lereng setelah dicampur Biopolimer Chitosan 2\%

Pengaruh perubahan parameter geser tanah setelah dilakukan stabilitas menggunakan biopolimer Chitosan 2\% dapat dilihat pada Tabel 3. Hasil analisis dari lereng yang seluruhnya mengalami keretakan dan terkena hujan lebat terhadap stabilitas diberikan pada Gambar 5. Berbeda dengan analisis stabilitas setelah diberi biopolymer, nilai safety factor semua di atas nilai SF rencana $\geq 1,5$.

Hasil pemodelan ini dapat digunakan untuk mewakili kondisi kemiringan aktual dalam kasus di Ruas Jalan Karanggede. Pada kenyataannya, lereng-lereng itu mengalami kelongsoran (sliding) selama hujan deras hingga sangat deras. Lereng stabil hanya ketika tidak ada hujan atau ketika hujan ringan sampai sedang. Oleh karena itu, konsep tanah retak dalam kondisi ekstrem (hujan sangat lebat) dapat menjelaskan kondisi sebenarnya dari kegagalan stabilitas terutama untuk tanah swelling soil.

Tabel 3. Perubahan Parameter Geser Tanah sebelum dan setelah Penambahan Biopolimer

\begin{tabular}{cccc}
\hline \multicolumn{2}{c}{ Tanpa Biopolimer } & \multicolumn{2}{c}{ Biopolimer CHI } \\
$\mathrm{c}(\mathrm{kPa})$ & $\boldsymbol{\phi}$ & $\mathbf{c}(\mathbf{k P a})$ & $\boldsymbol{\phi}$ \\
\hline 0 & $12,20^{\circ}$ & 17,544 & $16,74^{\circ}$ \\
\hline
\end{tabular}

Desain struktur pada lereng harus didasarkan pada asumsi bahwa lereng awalnya berisi beberapa retakan. Retakan ini diakibatkan oleh jenis tanah swelling soil yang sangat sensitif terhadap perubahan kadar air. Dengan pendekatan retakan tanah, faktor keamanan lereng semua lebih rendah dari 1, yang berarti lereng berpotensi longsor. Pengaruh 3 indikator baru konsep crack soil terhadap stabilitas lereng sesuai dengan hasil penelitian lapangan yang dilakukan oleh (Alexsander et al., 2017, 2018). Indikator baru yang mempengaruhi stabilitas lereng adalah: parameter kekuatan geser tanah dalam kondisi retak, posisi retakan (kedalaman dan arah retakan), dan intensitas hujan. Besarnya nilai untuk parameter geser tanah retak diperoleh dengan menggunakan alat pengujian geser dimodifikasi, dirancang khusus untuk menentukan nilai parameter geser tanah retak(Hutagamissufardal et al., 2017, 2018; Mochtar \& Hutagamissufardal, 2016). Arah dan kedalaman retakan di lapangan dapat diperoleh dari pengujian lapangan, seperti yang telah dilakukan oleh (Alexsander et al., 2017, 2018). Seperti yang telah dijelaskan, sebagian besar curah hujan dengan intensitas sangat deras yang mempengaruhi stabilitas lereng. Hujan dengan intensitas tinggi ini akan menyebabkan air hujan yang menembus ke lereng melalui celah-celah semakin banyak. 
Akhirnya, laju air hujan yang masuk melebihi kemampuan retakan untuk mengalirkan air keluar sehingga di dalam retakan tekanan air pori akan terus menumpuk sampai tekanan maksimum tercapai. Kondisi terakhir ini pada akhirnya akan menyebabkan kelongsoran lereng. Jika hujan tidak lebat, retakan hanya akan terisi sebagian oleh air hujan dan tekanan air di dalam retakan relatif kecil, sehingga lereng umumnya stabil.

Dari hasil penelitian ini didapatkan bahwa biopolimer, Chitosan mampu memperbaiki karakteristik tanah swelling soil. Perbaikan nilai parameter geser tanah dapat meningkatkan stabilitas lereng tanah swelling soil.

\section{Kesimpulan}

Dari penelitian ini dapat disimpukan bahwa pemberian biopolimer $\mathrm{CHI}$ meningkatkan nilai konsistensi tanah dari sebelumnya sangat lunak $\left(\mathrm{qu}<0,25 \mathrm{ton} / \mathrm{ft}^{2}\right)$ menjadi konsistensi kaku $(1<\mathrm{qu}<2$ ton/ $\mathrm{ft}^{2}$ ). Biopolimer Chitosan 2\% mampu memperbaiki karakteristik tanah swelling soil. Perbaikan nilai parameter geser tanah dapat meningkatkan stabilitas lereng tanah swelling soil. Dari hasil penelitian didapatkan safety factor lereng sebelum dilakukan improvement dengan biopolymer adalah 0,305 dan safety factor setelah dilakukan improvement dengan biopolimer adalah 2,006. Dari hasil penelitian ini terlihat bahwa peran biopolimer dalam meningkatkan stabilitas lereng (safety factor) tanah swelling cukup besar, yaitu sekitar 558\%.

\section{Ucapan Terima Kasih}

Ucapan terima kasih disampaikan kepada Pusat Penelitian dan Pengabdian kepada Masyarakat Politeknik Negeri Bandung, Jurusan Teknik Sipil Politeknik Negeri Bandung, dan Program Pascasarjana Rekaya Infrastruktur Politeknik Negeri Bandung atas dukungannya dalam penyelesaian penelitian ini. Penelitian ini merupakan keluaran dari Penelitian Mandiri tahun 2021 Politeknik Negeri Bandung.

\section{Daftar Pustaka}

Alexsander, S., Mochtar, I. B., \& Utama, W. (2017). The Measurements of Water Intrusion through Cracks Propagation Inside Slopes to Explain the Cause of Slope Failure - Case Study of Embankment in the Sanggu- Buntok Airport, Central Kalimantan, Indonesia. Electronic Journal of Geotechnical Engineering (EJGE), 22(14), 5347-5362.

Alexsander, S., Mochtar, I. B., \& Utama, W. (2018). Field Validated Prediction of Latent Slope Failure Based on Cracked Soil Approach. Lowland Technology International, 20(3), 245258.

Amalia, D., Mochtar, I. B., \& Mochtar, N. E. (2019). Application of digital image technology for determining geometry, stratigraphy, and position of cracks inside earth slope. International Journal of GEOMATE, 17(63). https://doi.org/10.21660/2019.63.25640

Amalia, D., Mochtar, I. B., \& Mochtar, N. E. (2020). Application of a New Concept of Cracked Soils in Slope Stability Analysis with Heavy Rain and the Pattern of Cracks as the Governing Factors. In Lecture Notes in Civil Engineering (Vol. 53). https://doi.org/10.1007/978-3-03032816-0_42

Amalia, D., Mochtar, I. B., \& Mochtar, N. E. (2018). Penerapan Konsep Baru Cracked Soils pada Penangulangan Kelongsoran Lereng (Studi Kasus: Pembangunan Gedung Reskrimsus Polda 
Kalimantan Timur, Balikpapan). "Industrial Research Workshop and National Seminar (Irwns) 9th Polban”, 50-63.

Chen, C., Peng, Z., Gu, J., Peng, Y., Huang, X., \& Wu, L. (2020). Exploring environmentally friendly biopolymer material effect on soil tensile and compressive behavior. International Journal of Environmental Research and Public Health, 17(23), 1-13. https://doi.org/10.3390/ijerph17239032

Departemen Pekerjaan Umum. (2004). Departemen Pekerjaan Umum tentang Jalan. In Departemen Pekerjaan Umum.

Elmannaey, A. S., Fouad, H. E. E., \& Youssef, Y. G. (2021). Improvement of swelling chlorite soil using sodium silicate alkali activator. Ain Shams Engineering Journal, 12(2), 1535-1544. https://doi.org/10.1016/j.asej.2020.10.019

Hutagamissufardal, Mochtar, I. B., \& Mochtar, N. E. B. (2017). The Effect of Soil Cracks on Cohesion and Internal Friction Angle at Landslide. The 6th International Conference of Euro Asia Civil Engineering Forum.

Hutagamissufardal, Mochtar, I. B., \& Mochtar, N. E. B. (2018). The Effect of Cracks Propagation on Cohesion and Internal Friction Angle for High Plasticity Clay. 13(5), 2504-2507.

Izzo, M. Z., \& Miletić, M. (2019). Sustainable improvement of the crack resistance of cohesive soils. Sustainability (Switzerland), 11(20). https://doi.org/10.3390/su11205806

Mochtar, I. B., \& Hutagamissufardal. (2016). Cracks in Soil and Their Implication for Geotechnical Engineering. Pertemuan Ilmiah Tahunan (PIT XX) 2016, 49-54.

Nursar, A. S., Iswan, \& Setyanto. (2015). Komparasi Nilai Daya Dukung Tanah Lempung Ditinjau dari Hasil Uji Skala Penetrasi Konus Dinamis, Uji CBR Laboratorium dan Uji Kuat Tekan Bebas. Jurnal Rekayasa Sipil Dan Desain (JRSD), 1(1), 193-204.

Pramudyo, Tulus; Sollu Willian Pradana; Hemawan, W. (2019). Atlas, Sebaran Batuan Lempung Bermasalah Indonesia (Vol. 1).

Setiawati, A., Catur, S., Prasetyo, A., Utomo, J., Hatmoko, D., \& Hidayat, A. (2015). Kuantifikasi Emisi Gas CO2 Ekuivalen pada Kontruksi Jalan Perkerasan Kaku. Jurnal Karya Teknik Sipil, 3, 83-92.

Soldo, A. (2020). Biopolymers for enhancing the engineering properties of soil.

Suherman. (2005). Potensi Sifat Ekspansif Tanah Kelempungan. Jurnal Jalan Dan Jembatan.

W. G. Holtz, \& H. J. Gibbs. (1956). Engineering Properties of Expansive Soils Vol. 121, 1956, pp. 641-679. Transactions of ASCE, 121, 641-679.

Wardana, I. G. N. (2009). Kelakuan Tanah Dengan Sifat Kembang-Susut Yang Tinggi Pada Stabilisasi Tanah Dengan Bahan Serbuk Marmer Dan Bahan Stabilia. Jurnal Ilmiah Teknik Sipil, 13(2). 